(vi) Greek Ac. Paul. et Thec. 3 : Small in size, baldheaded, bandy. legged, of noble mien, with eyebrows meeting, rather longnosed, full of grace, sometimes like a man and sometimes like an angel.

It will be observed that the borrowed Arabic description of St Mark varies at three points with the Armenian against the Greek.

There can be no doubt that the description of the Apostle is Petrine. This is shewn not only by the parallels to the allusions to his hair and legs, but also by the statement that he sometimes looked like a man and sometimes like an angel. We compare the vision which Abgar saw appear on the face of Thaddaeus and before which he prostrated himself (Eus. H.E. I xiii 13 ), and also Ac. Thom. 8 where the flute-girl looks at Thomas whose form changes. She says, This is either God or God's apostle. Both incidents are related to $A c$. $\times 25 \mathrm{f}$, the source of which passage, I shall shew, much influenced the Acta.

The Armenian recension of the Story of Thecla is undoubtedly, as Conybeare argues, superior to the Greek, but it is not likely to represent the earliest form of the story unless the story was in its earliest literary form adapted to some depraved Acts of Peter, a hypothesis which is exceedingly improbable. That the opening is Petrine is shewn by the parallelism with $E P$ p. 7 , where the tetrapylon must be that of Caesarea and original. In each case the Apostle preaches immediately on his arrival and borrows his sermon from the same book.

H. J. Bardsley.

\title{
ST AMBROSE AS AN INTERPRETER OF HOLY SCRIPTURE.
}

Allegorical interpretation of the Scriptures has been described as ' a convenient method of interpretation by which anything whatever can be made to prove anything one likes'.' But it was employed by St Clement of Alexandria, Origen, St Ambrose, and St Augustine-to make no mention of smaller names-and is a chapter in the history of Biblical exegesis which cannot be ignored. At the beginning of the Christian era it was known in Jewish circles. Philo" ${ }^{2}$ found in it a means of combining Hellenic philosophy with Jewish religion.

1 H. F. Hamilton The People of God i p. 224.

2 DCB. s. v. Philo. 
It was also useful as a means of meeting the charges which might be brought against the Old Testament by cultivated pagans who urged that its picture of God is unduly anthropomorphic, that it inculcates barbarous wars, and commends actions of questionable morality. For those who were already believers it shewed that the sacred text possessed richer stores of meaning than they had supposed.

Traces of it appear in the New Testament. ${ }^{1}$ Classical scholarship had applied it to Homer as a means of meeting the moral difficulties raised by his portraiture of the gods. ${ }^{2}$ It was therefore perfectly natural that Christian writers should feel themselves at liberty to interpret the Scriptures, particularly the Scriptures of the Old Testament, allegorically if they wished to do so, and Alexandria soon became the head-quarters of this school. The allegorical method was adopted by the great Gnostic teachers who flourished there during the first halt of the second century and their practice was accepted by the Church. It was too valuable a weapon for the Christian apologist to ignore.

Thus the "Epistle of Barnabas' 8 teaches that the law never had any literal significance at all. The directions of Leviticus as to unclean animals really refer to various classes of sinners whom the Israelites were to avoid.* The scape-goat is nothing but a type of Christ. ${ }^{5}$

The idea of a Christian $\gamma \boldsymbol{\omega} \hat{\omega} \sigma$ ss which is to be attained by studying the deeper meaning of the Scriptures appears in the epistle. ${ }^{6}$

But the real father of Christian Allegorism is St Clement of Alexandria. It was firmly established by him in the Catechetical School and so became the tradition of the Alexandrine Church. If he needed authority for it he found it in a book which he regarded as inspired Scripture. Hermas relates how the woman (representing the Church)

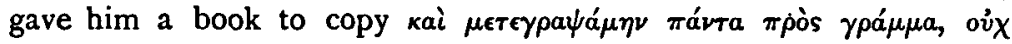

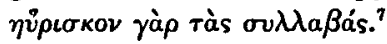

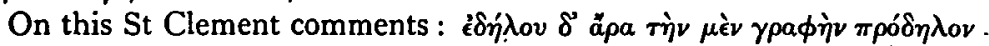

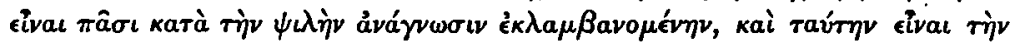

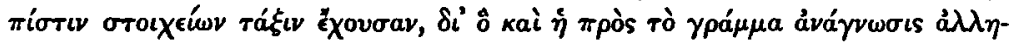

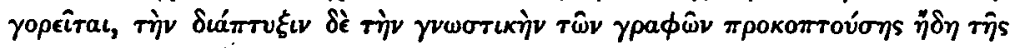

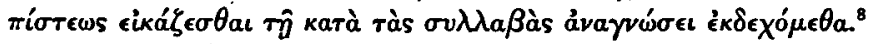

With St Clement it is a principle that almost all Scripture has an esoteric meaning which is to be grasped by the 'advanced' Christian

1 I Cor. $x$ 4, Gal, iv 24-28, St Matt. xii 40.

2 Xenophanes (Ritter and Preller, p. 78). Cf. also R. Jebb Introduction to Homer p. 89 ; H. Browne Homeric Study p. 30 ; Longinus $\pi \epsilon p i$ úf

3 'An Alexandrian writing of the time of Hadrian'-H. B. Swete The Holy Spirit in the Ancient Church p. I8.

i $\mathrm{X}$. 3 VII.

7 Pastor Uis. II.

- XVIII.

${ }^{8}$ Strom. VI xv izI. 
reader. 'Elementary' Christians will not get below the superficial meaning :-

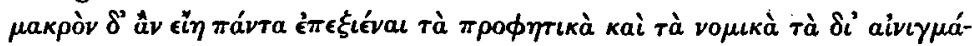

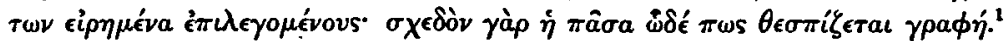

There may be as many as four classes of meaning in a single passage, literal, mystic (i.e. allegorical), moral, and prophetic. ${ }^{2}$

Two kinds of allegorical meaning may be found in the stories of the Old Testament. An incident beside being a historical event which did actually take place may symbolize some external spiritual truth. Thus - to take a single example-the stripping of Joseph and the casting him into the pit expresses the hostility always felt by the ignorant against the more enlightened. ${ }^{3}$

Or an incident may prefigure the Life of Christ and anticipate some detail of it. Thus the Burning Bush may be regarded as an earnest of the Incarnation and prefigures our Lord's Crown of Thorns."

Origen adopted allegorism ex animo and all his exegetical writings are permeated with it. But his use of it differs somewhat from that of St Clement. St Clement thinks primarily of the faithful whom it may edify; Origen of the enemies whom it may overthrow. In his eyes it is one of the most valuable weapons which the Church can wield against the unbeliever, and his first task is therefore to place it on a scientific basis. He has to shew not merely that Scripture has commonly been interpreted in this way, but that the Church is entitled to prefer this method to any other. Any objection to the Scriptures which can be met by allegorism can no longer be considered to be of any weight at all.

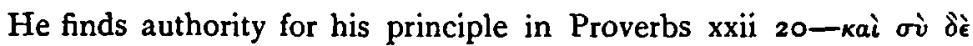

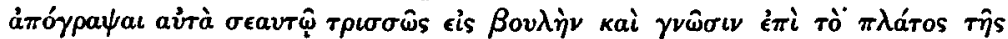

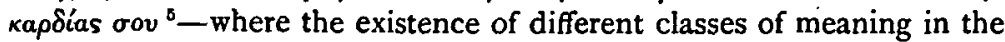
Scriptures seems to him to be explicitly asserted.

The adoption of this principle makes the literal meaning of any passage wholly unimportant. Indeed it is doubtful whether the Bible

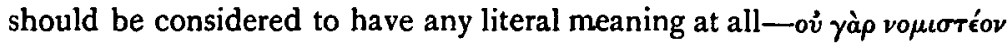

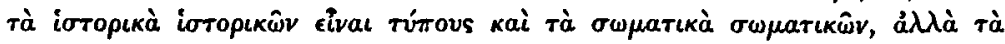

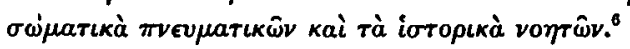

In this way many of the difficulties raised by the Old Testament can be met. The wars of extermination said to have been waged by the Israelites never took place at all. They represent the struggles of the soul with its besetting sins. But where incidents which are historical

I Ib. V vi 32. $16 . \mathrm{I}$ xxviii $176 . \quad 316 . \mathrm{V}$ viii $54 . \quad 1$ Paed. II viii 75

b Have I not written unto thee excellent things of counsels and knowledge? $R$.V.

- In Ioann. $\times 18$. 
are open to moral criticism the difficulty is met by postulating a higher and a lower kind of truth. The ideal is to maintain both. But when this is impossible the lower must be sacrificed. Thus what may appear at first sight to be deceit is justifiable as being the only means of conveying spiritual truth. 'The spiritual truth', he says, 'is often preserved in what may be called the bodily lie.' ${ }^{\prime}$

Thus Jacob was justified in passing himself off as Esau. As Esau had already forfeited his birthright, Jacob had obtained a spiritual seniority which entitled him to assume the externals of his brother's character. ${ }^{.}$The events related in the Gospel have more than a historical significance. For example; the Entry of our Lord into Jerusalem represents the entry of the Word of God into the soul. Every detail of the narrative has its counterpart in the spiritual experience of the individual believer as he receives the word through the medium of the Scriptures-'I $\eta \sigma o v$ s roivvv

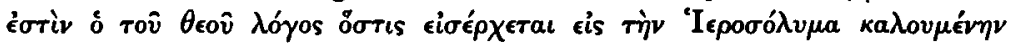

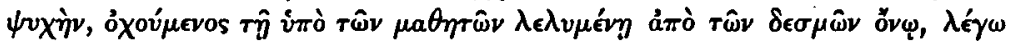

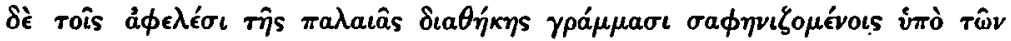

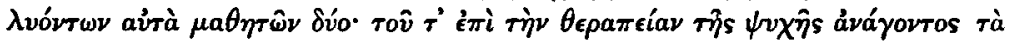

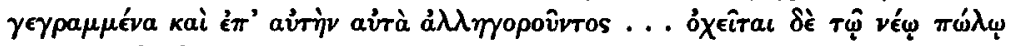

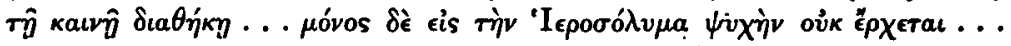

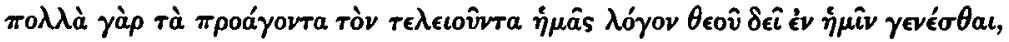

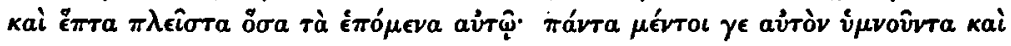

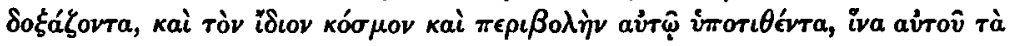

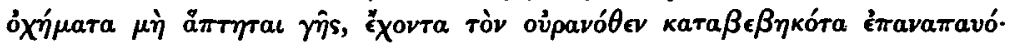

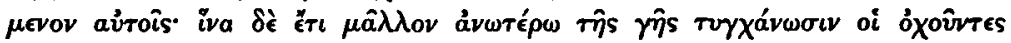

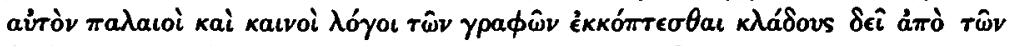

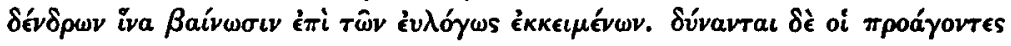

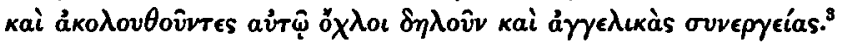

It is unnecessary to multiply quotations from Origen's writings. $\mathrm{He}$ reads the Bible without any historical perspective whatever. Any passage may. be taken in conjunction with any other and the value of the Scriptures does not reside in what they seem to say but in the 'mystical' meaning which they skilfully conceal. To expound this inner meaning is the principal task of the Christian student. The value of Origen's method has been summed up as follows: 'It is at once elusive and fruitless. He finds in it a convenient method of compelling Scripture to yield an answer to the many speculative questions that agitate his own restless brain. But it is no proper or satisfying answer that he thus obtains. As a Jew even Philo had to pay some regard to the literal and historical sense of the Old Testament; but the reins of Origen's imagination knew no such restraining influence. For him allegorical exegesis meant licence to father his own speculations
I I6. $\times 5$.
216 .
B $16 . \times 28$. 
upon a sacred text which was venerated as the depository of all truth.' 1

But to Origen and his contemporaries the results obtained by this method were entirely satisfactory. Allegorism became firmly established as one of the most valuable weapons of the Church's armoury. Except at Antioch its usefulness was hardly questioned, and although the Antiochene school claimed many distinguished adherents ${ }^{2}$ the fact that the Arians looked back to Lucian as in some sense their master must have tended to bring it into disrepute. Allegorism and orthodoxy seemed to stand or fall together ${ }^{3}$ : especially when Alexandria became in the person of Athanasius the stronghold of the Catholic Faith.

Allegorism had been introduced into the Western Church at least as early as the time of Hippolytus. In the fourth century it might be said to be demanded by Catholic tradition. Certainly those to whom it appealed could justify their use of it by saying that it was so demanded. There is nothing surprising in its adoption by any fourth-century writer unless he were avowedly a disciple of the school of Antioch. And there were special reasons why it should be adopted by St Ambrose.

I. Auxentius, his immediate predecessor in the See of Milan, had been an avowed Arian and Arianism was strongly entrenched at the Imperial Court. A new bishop who wished to place his own orthodoxy above suspicion could do so most easily by adopting whole-heartedly the tradition of Alexandria.

2. St Ambrose had had no Christian training before he was elected bishop, and from the very beginning of his episcopate laid great stress on the teaching side of his office." But as he was not fitted by his antecedents to undertake any original departure he would naturally expound the Scriptures according to whatever method seemed to him to possess the greatest weight of Church-Authority.

His veneration for the Scriptures was profound, and he quickly became very familiar with their contents. His power of quotation, whether relevant or not, is extraordinary. He was never tired of preaching expository sermons, and St Augustine has paid a noteworthy tribute to their value.

Like Origen, St Ambrose recognized that the sacred text contains much which is beyond human comprehension. ${ }^{\circ}$ But he felt that there is no more worthy task than to elucidate their mysteries as far as possible.

1 W. Fairweather Origen and Greek Patristic Theology p. 78.

2 Malchion, Lucian, Dorotheus, Chrysostom, Diodorus, Theodoret, Theodore of Mopsuestia.

- Cf. J. H. Newman Arians of tite Fourth Century p. 414.

- Paulinus Uita 38.

- De Paradiso ii 7 (cf. Philocalia ii 2). VOL. XVI. 
The following is a complete list of his extant exegetical writings :-

Title.

De Paradiso

De Cain et Abel

De Tobia

De Noe et Arca

Apologia Prophetae Dauid

De Interpretatione Job et Dauid

Expositio in Lucam

Hexaemeron

De Elia et Ieiunio

Expositio in Ps. cxviii

De Abraham

De Isaac et anima

De Iacob et Uita Beata

De Ioseph Patriarcha

De Benedictionibus Patriarcharum

De Nabuthe Iezraelita

Enarratio in xii Ps. Dauidicos
Date.

Between 375 and 378 .

Between 376 and 379 .

377 (irca).

$3^{80 .}$

Soon after Aug. 25, $3^{83}$.

$3^{8} 3^{-384}$.

$3^{86-387}$.

Soon after 386 .

After 386 .

387-388.

$3^{87-390 .}$

After $3^{86 .}$

At intervals between $381-397$.

The dates are ascertainable chiefly from internal evidence. In three instances they are clear. Ap. Proph. Dauid (vi 27) and En. in Ps. lxi (xvii 26) refer to the death of Gratian (Aug. 25, 383) as a recent event. $E n$. in Ps. xxxvi (xxv) alludes to Theodosius's victory at Aquileia (Sept. 6, 394).

En. in Ps. xliii is said to have been dictated from his death-bed ${ }^{1}$ and therefore belongs to the last days of March 397.

With the exception of De Elia, De Tobia, and De Nabuthe, which seem to have been preached to ' general corrgregations', these expositions seem to have been originally sermons intended primarily for Catechumens. They do not aim at confuting unbelievers but rather at removing the difficulties to which the Scriptures must give rise in the minds of those who wish to believe. These were naturally more acute where the Old Testament was concerned. Except for the series which may be called 'Studies in the Lives of the Patriarchs', St Ambrose does not seem to have been guided by any principle in his selection of subjects.

We must illustrate his method and the results which it yielded by means of quotations, and then endeavour to estimate his debt to previous writers and his influence upon his successors.

I. His Principle.

The Method of St Ambrose.

He follows St Clement and Origen in adopting a threefold sense

1. Paulinus Uita 42. Cf. also M. Ihm Studia Ambrosiana (Leipzig 1889). 
of Scripture. But not every passage can bear the triple interpretation. Some may belong entirely to one class. Genesis may, be called collectively naturalis, because it tells the story of Creation: Leviticus mysticus, because it contains the mystery of the Priesthood; Deuteronomy moralis, because it contains the precepts of the Law.

The three books of Solomon correspond with these three classes. ${ }^{1}$

Beside this the division of wisdom-traditionally ascribed to Plato ${ }^{2}$ into three classes is accepted. ${ }^{s}$ These St Ambrose calls Rationalis, Moralis, Naturalis. These are symbolized by the three wells dug by Isaac (Gen. xxvi 20-23). Ezek = Uisio = Sapientia Rationalis; Sitnah $=$ Abundantia $=$ Sapientia Moralis; Rehoboth $=$ Iuramentum $=$ Sapientia Naturalis.

He gives no reason for these equations, which are not derived from

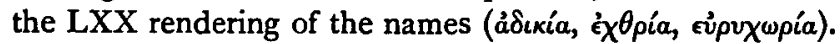

The books of Solomon shew him to have been equally proficient in each class. The Evangelists are not deficient in any branch, but St John may be considered to have excelled in Sapientia Naturalis, St Matthew in Moralis, St Mark in Rationalis. St Luke's Gospel exhibits the highest degree of each."

Of the three interpretations which the Scriptures can bear the mystical is the most important :-

In mysticis fructus est, in moralibus folium . . nam uirtutes sine fide folia sunt ... haec forte sunt folia quae Saluator in illa ficu reperit, sed fructum non inuenit. Mystica saluant et a morte liberant: moralia autem ornamenta decoris sunt non subsidia redemptionis. Praestare autem mystica moralibus etiam ipse Dominus docet in euangelio suo dicens de Maria ... Martha Martha, Maria optimam partem sibi elegit quae non auferetur. ${ }^{\circ}$

Enough has been said to shew what was the general attitude of St Ambrose to the Bible as a whole. In his eyes it is really a species of sacred cypher. The plain, obvious meaning of any passage is never the whole of what it is intended to mean to the Christian reader. Faith lives by the deeper meanings which can be disinterred, and the task of the Christian teacher is to lay these before his audience. To this task St Ambrose brought an utterly uncritical mind, unhampered by any knowledge of Hebrew or by any considerations of historical perspective. He is like a man turning over an immense heap of variously shaped fragments. What the original design may have been does not concern him. He merely fits them together as his fancy prompts into wholly unexpected patterns. It is a laborious exercise and one which could only be undertaken by the possessor of a retentive
1 Praef. in Ps. xxxvi.
3 Praef. in Luc. 2.
I Ib. 4 .
L 12
${ }^{8}$ Cr. Aug. De Ciu. Dei VIII iv.
s In Ps. 4r, $_{4}$. 
memory coupled with great power of application. No doubt as to the value of the patterns which he formed seems ever to have crossed his mind.

\section{His Results.}

We must give examples of his handling of each of the three classes of meaning which he recognized :-

\section{A. Naturalia.}

It is not easy to see exactly what St Ambrose understood by the naturalis sensus of a passage. Certainly he understood by it more than we should understand by the 'literal sense'. The book of Genesis may be called collectively naturalis, but that does not mean that no part of it is susceptible of allegorical interpretation.

Naturalia are more than the historical facts related. For instance, the reason why Noah took seven of the various species of clean animals into the Ark is to be explained by the fact that seven is in itself a clean, sacred, virgin number. And the discussion of the various properties of the number Seven ends with the words Haec naturalia."

Another example of 'natural' interpretation is when the structure of the ark is compared with that of the human body. The passage is sufficiently important to be quoted at length :-

- 'Sed iam de ipsa Noe arca dicendum² quam si quis uelit impensius considerare inueniet in eius aedificatione descriptam humani figuram corporis. Quid est enim quod ait Deus Fac igitur tibi arcam de lignis quadratis. Quadratum certe hoc appellamus quod omnibus bene consistat partibus et conveniat sibi. Itaque et Deus auctor nostri corporis ... opus ipsum perfectum esse iis sermonibus significatur. Quadrata autem hominis membra esse euidens ratio, si consideres pectus hominis, consideres uentrem pari mensura longitudinis et latitudinis ... . iam pedes et manus brachia femora et crura quadripartita quis non ipso uisu aduertat?

Quid etiam sibi uult quod ait Nidos facies in arca ... naturaliter enim dictum arbitror eo quod omne corpus nostrum attextum est sicut nidus ... nidi quidam sunt oculi nostri ... nidi sunt nostrarum sinus aurium ... nidus est narium . . . nidus est quartus maior ceteris hiatus oris ... unde uox euolat. Unde et puto et illum in psalmo non solum mystice sed etiam naturaliter dixisse Passer inueniet sibi domum et turtur nidum ubi reponat pullos suos.'"

In a sense this might be called an allegorical interpretation of the passage. But in the eyes of St Ambrose it is not 'mystical' because the ark symbolizes a material object : not an event in the Life of Christ or any spiritual truth.

The extract quoted above will be sufficient to shew that the exigencies

1 De Noe et Area xii 39.

Ib. vi.

ss. Ixxxiii 4 . 
of naturalia impose no serious check upon the imagination of the expositor.

\section{B. Moralia.}

By moralia St Ambrose meant ethics. Although he subordinates them to mystica he was not blind to their importance. He dwells on the need of Christian living ' and attacks the sins of the timeespecially usury, drunkenness, and fraudulent trusteeship with great vigour and shrewdness. For this purpose he makes most use of St Luke's Gospel and of the lives of the Patriarchs, pointing out that the characters of the Old Testament are to be regarded as warnings as well as examples. ${ }^{2}$

In this region neither his method nor his results call for special comment. A modern preacher would have no difficulty in using many of his sermons on Moralia.

\section{Mystica.}

St Ambrose nowhere states whether a commentator of sufficient spiritual insight could interpret every passage of Scripture 'mystically' or not. But a 'mystical' interpretation is to be found wherever possible. Reference to Christ, the Church and the spiritual experience of the individual soul are to be sought on every page of the inspired writings.

The following extracts are typical examples of the results which he obtained :-

I. Adam enim mentem diximus (De Paradiso ii) Euam sensum esse significauimus, serpentis specie delectationem expréssimus . . . purgauerat enim terram Dominus diluuii infusione ... . sed non satis erat ad uirtutis profectum, nisi ut instrueretur homo quemadmodum se regeret et gubernaret. Abraham mentis loco inducitur. Denique Abraham transitus dicitur. Ergo ut mens quae in Adam totam se delectationi et illecebris corporalibus desiderat in formam uirtutis speciemque transiret uir sapiens nobis ad imitandum propositus est. Denique Abraham pater dictus est eo quod mens paterna quadam auctoritate ... totum gubernat hominem. Haec ergo mens erat in Charra, id est in cauernis obnoxia uariis passionibus. Ideoque dicitur ei Exi de terra tua, id est de corpore tuo. . Exiuit de hac terra ille cuius conuersatio in caelis est. Et de cognatione inquit tua. Cognati sunt animae nostrae corporis sensus. Et de domo tua inquit exi. Dominus mentis. prolatiuum est uerbum. Sicut enim paterfamilias habitat in domo sua ... ita etiam mens in sermonibus nostris habitat ... et uis eius et disciplina in sermone elucet. ${ }^{3}$

It is difficult to tell whether he regarded the Fall and the Migration of Abraham as actual historical events or not. If they are history their principal permanent value for the Christian reader lies in the 'mystical' meaning which can be read into them.

\footnotetext{
1 e.g. in Ps. cxuiii I. ${ }^{2}$ e.g. De Abraham I vi ${ }_{5} 8 . \quad$ s De Abraham II 1.
} 
2. The meeting between Isaac and Rebekah prefigures the Church. Isaac represents the human soul which is attracted by the Church's beauty. Or he may represent Christ, to whom the Church gives herself as bride.

Ergo uel anima patriarchae uidens mysterium Christi, uidens Rebeccam uenientem cum uasis aureis et argenteis tanquam ecclesiam cum populo nationum, mirata pulcritudinem uerbi et sacramentorum eius dicit Osculetur me ab osculis oris sui. Uel Rebecca uidens uerum Isaac, uerum illud gaudium, ueram laetitiam, desiderat osculari."

The story in St Luke's Gospel (vii $3^{6-50}$ ) of the woman who kissed our Lord's feet is cited as parallel.

3. Commenting on St Luke xxii $3^{6-3^{8}}$ he writes :-

Domine cur emere me iubes gladium qui ferire me prohibes? . . . Multis hoc iniquum uidetur, sed non iniquus Dominus ... est enim gladius spiritalis ut uendas patrimonium, emas uerbum quo nuda mentis penetralia uestiuntur. Est enim gladius passionis ut exuas corpus et immolatae carnis exuuiis ematur tibi sacri corona martyrii.

Mouet tamen adhuc quod duos gladios discipuli protulerunt ne forte unum noui alterum ueteris testamenti quibus aduersus diaboli armamur insidias? Denique dicit Dominus Satis est, quasi nihil desit ei quem utriusque testamenti doctrina munierit. ${ }^{2}$

He would not have doubted the historical character of the incident. But be is not content to treat it solely as bistory. It is, as it were, an episode in a drama the value of which for edification lies in its allegorical. significance.

\section{His debt to previous writers.}

As a disciple of the Alexandrine School St Ambrose was acquainted with the writings of Philo and of Origen. He mentions Philo by name once $^{3}$ and Origen three times." On at least five occasions he controverts Philo for the ultra-Jewish character of his exegesis without naming him. ${ }^{5}$ He must presumably have been acquainted with the writings of St Clement, but I have not been able to notice any direct reference to him.

But while in general agreement with the Alexandrines St Ambrose seems to have borrowed directly from two writers only : St Hippolytus and St Basil. With St Basil he had personal relations. ${ }^{\circ}$

1 De Isaac et Anima iii 7,8 . For the debt of the whole treatise to Hippolytus's commentary on the Song of Songs, see M. Bonwetsch Texte u. Unter.N.F. viii a (Leipzig 1902).

2 Expos. in Luc. $\times 53-55$.

- De Abraham II viii 54 ; In Ps. 118 iv 16 ; Ep. 75. 1 .

- Ep. 28, I; De Parad. II II ; De Cain et. Abel I viii 32 ; De Fuga III iv 20 ; De Noe v 12. I am indebted for these references to P. de Labriolle Saint Ambroise, esp. pp. 163-180 (Bloud et Cie, Paris).

- Cf. St Basil Ep. 197 . 
The indebtedness of his treatise De Isaac et Anima to St Hippolytus's commentary on The Song of Songs has been discussed by Bonwetsch (vide supra p. II note), and it is therefore unnecessary to go over the ground again.

St Basil published some homilies on the Six Days' Work of Creation as related in the opening chapters of Genesis under the title Hexaemeron. This furmished St Ambrose with a model for a similar set of discourses. He copies St Basil's title and arrangement of the subject. In some places he translates the Greek directly.

But it would not be fair to call the Hexaemeron of St Ambrose a mere reproduction of St Basil's work. The differences between them are often very wide and are due to a considerable difference between their general mental attitudes.

I. St Basil expressly disavows the allegorical method-oióa vómovs

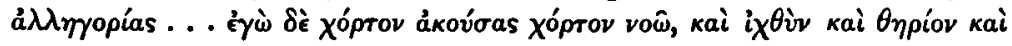

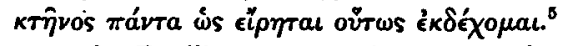

2. St Basil's purpose is apologetic. He seems to have in mind readers in whose eyes the authority of the Bible is still an open question. $\mathrm{He}$ aims at shewing that the Scriptures are thoroughly reasonable and throw light on many questions which philosophers have found insoluble. They have, therefore, an irrefragable claim upon all unprejudiced minds.

The purpose of St Ambrose is entirely exegetical. In his eyes the divine authority of Scripture is beyond question, and he assumes that this is recognized by his audience. But the meaning of the Sacred Text is often obscure and commonly far richer than the ordinary reader would suspect. His task is to edify the faithful by shewing them how great these hidden treasures of meaning really are.

The following extracts will illustrate his debt and his independence.

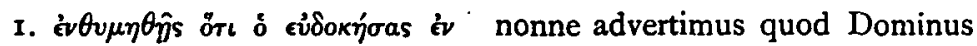

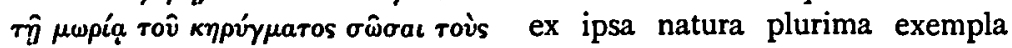

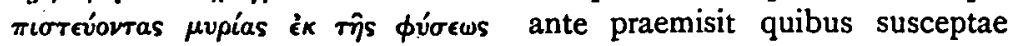

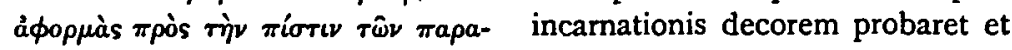

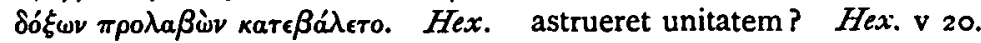
viii 6.

The matter in hand is the Birth of our Lord from a Virgin. Both refer to the belief that vultures lay without having mated. But their use of the analogy is different. To St Basil the Christian belief is a matter of difficulty. But nothing in the Gospel is more incredible than the admitted wonders of nature. Nature forbids us to say that anything is impossible. To St Ambrose Faith needs no such assistance.

1 Hex. ix 1. 
But God has so ordered the working of the natural world that it points to the Incarnation and makes it perfectly natural that the Birth of Christ should have been as it was.

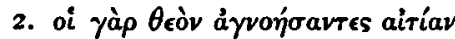

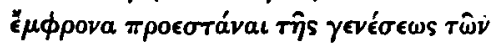

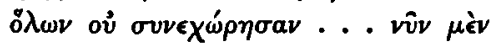

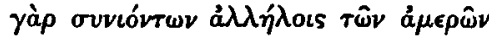

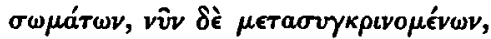

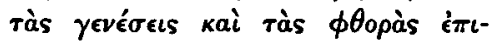

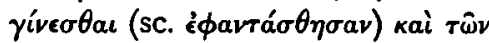
ठцаркебтє́

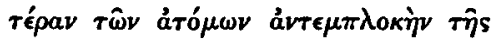

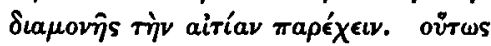

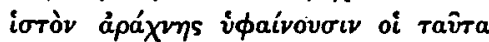

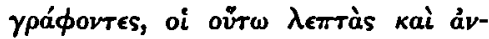

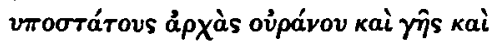

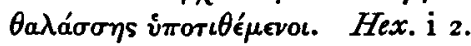

aduertit enim uir plenus prudentiae (sc. Moses) quod uisibilium atque inuisibilium substantias origines et causas rerum mens sola diuina contineat, non ut philosophi disputant ualidiorem atomorum complexionem perseuerantiae iugis praestare causam : sed iudicauit quod telam araneae texerent qui sic minuta et insubstantiua principia caelo ac terris darent.

Hex. i 2.

In St Basil's eyes materialistic views of the origin of the universe stand condemned by reason. To St Ambrose they are equally irrational, but they are condemned primarily by the authority of Moses.

3: When commenting on Gen. i 9 (Hex. iv 2) St Basil dwells exclusively on the physical aspect of the act. He refers to the natural properties of water and to the difficulties which might be felt in view of the fact that all the water on the surface of the earth is not now in one place, but is distributed in widely separated seas.

St Ambrose ignores all questions of this kind (Hex. iii 3). To him the gathering of the waters represents the recruiting of the Church from the whole world and the separation of the faithful from heretics.

4. Both St Basil and St Ambrose published homilies, originally delivered in the form of sermons, upon selected Psalms. Their selections are not the same, but we have discourses from both upon Psalms i, xlv, xlviii, and lxi. In these St Ambrose shews a debt and an independence similar to that which he shews in the Hexaemeron.

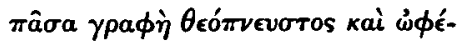

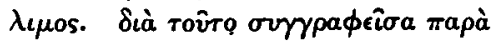

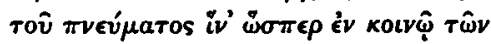

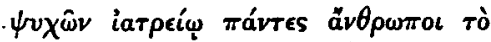

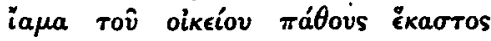

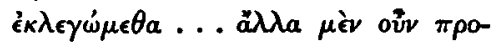

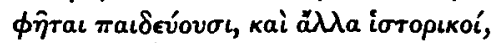

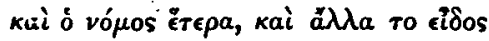

etenim licet omnis Scriptura diuina Dei gratiam spiret, praecipue tamen dulcis psalmorum liber ... historia instruit, lex docet, prophetia annuntiat, correptio castigat, moralitas suadet: in libro psalmorum profectus est omnium et medicina quaedam salutis 


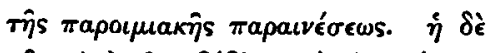

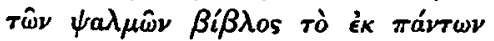

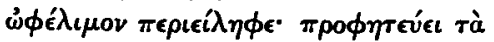

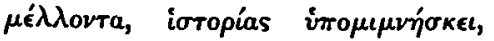

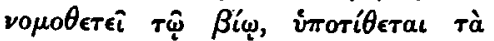

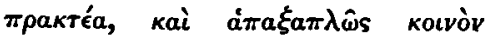

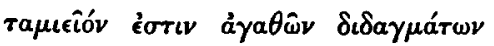

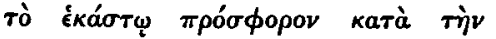

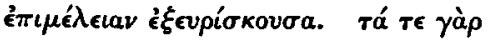

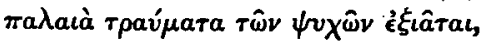

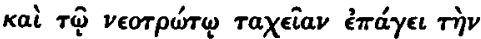

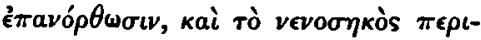

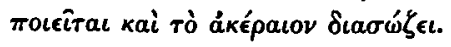

In Ps. i $\mathrm{I}$. humanae. Quicumque legerit habet quo propriae uulnera passionis speciali possit curare re. medio. Quicumque curare uoluerit tamquam in communi animarum gymnasio et quodam studio uirtutum diuersa genera certaminum reperiens praeparata id sibi eligat cui se intelligit aptiorem quo facilius perueniat ad coronam.

In Ps. i 4 and 7.

To St Basil the infrinsic merits of the psalter need no external justification. But while St Ambrose recognizes them fully he finds an additional reason for regarding the psalter as the flower of the Bible in the fact that Moses had recourse to song after two of the great crises of his life (Exod. xv, Deut. xxxii).

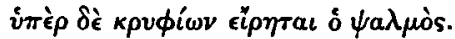

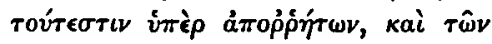

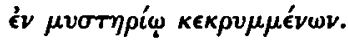

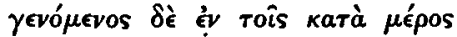

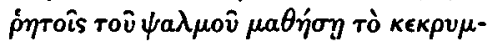

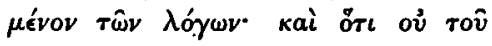

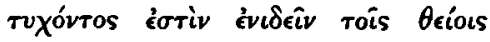

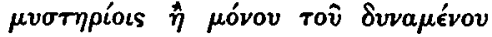

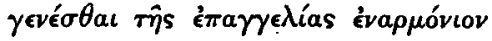

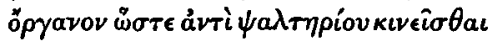

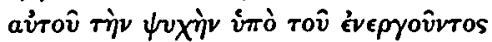

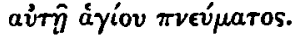

In Ps. xlv I.
Quid est Pro occultis? . . quae autem illa sint occulta in euangelio sancto docemur, dicente Dei Filio quod mysteria sapientiae abscondita sint sapientibus et paruulis reuelata. Haec sunt illa, ni fallor, quae oculus non uidit nec auris audiuit nec in cor hominis ascenderunt quae praeparauit dominus diligentibus eum. Ergo in occulto cordis nostri occulta sapientiae recordamus, non temere aliquibus diuulgemus nisi sacramentorum consortibus quos dominus uocauit ad gratiam suam, qui se in abscondito uult rogari, quoniam solus est qui abscondita et occulta cognoscat. In Ps xlv I.

The influence of St Ambrose upon succeding writers.

The correspondence of St Ambrose shews how highly his contemporaries esteemed his exegetical powers. Many of his letters shew that he had been asked to interpret some perplexing passage. But his 
correspondents were not men of literary distinction, and we have therefore no means of knowing how closely they followed him.

The writer in whom we should naturally expect to find most traces of his influence is St Augustine. St Augustine has told how much he owed to the sermons of St Ambrose upon the Bible (vide supra, p. $5^{1} 3^{n}$.), and we might therefore expect to find him reproducing his master. But his debt to St Ambrose is general rather than particular.

$\mathrm{He}$ accepts a fourfold division of Old Testament Scripture, ${ }^{1}$ and dwells on the importance of recognizing where any given passage demands an allegorical interpretation. ${ }^{2}$ To take literally a passage which is meant to be understood allegorically is a mark of carnalmindedness. But he does not surrender himself completely to allegorism. To him it is one valuable line of interpretation, but only one. It is to be adopted where no other method seems to yield satisfactory results. ${ }^{3}$ Accordingly many passages are to be interpreted partly historically and partly allegorically." In his writings both upon the Book of Genesis and upon the Psalms he makes full use of the method which he had learned from St Ambrose. But the thought is always his own. I have not been able to notice any certain instance of direct borrowing.

St Ambrose had not sufficient originality to make him an attractive model for successive writers. His strength lay primarily in his conduct of affairs. He was remembered as one who had ruled wisely and firmly in his day, and had valiantly upheld the rights of the Church against aggression in high places, more than as a thinker and a theologian.

But more than any other single figure he established allegorism in the west. He made the Alexandrine method of interpreting the Scriptures familiar to Latin readers. The fact that St Augustine gave it a still wider currency was due primarily to him.

But as a method of interpretation it had its own dangers. Those who used it might easily overrate the value of their own subtleties and treat them as profound divine truths. And allegorism might become so fantastic as to defeat its own ends by exciting the ridicule of the pagans whom it was designed to convert. St Jerome was keenly alive to this possibility, and saw the need of emphasizing the historical sense. ${ }^{5}$

But though allegorism fell somewhat into abeyance immediately after St Ambrose's own time it never died. It revived during the Middle Age, and his influence was probably stronger then than at any earlier period.

R. H. Malden.

1 De Utilitate Credendi iii. (Cf. De Genesi ad Literam c. II.)

2 De Doctr. Chr. iii g. (I owe both these references to W. Cunningham S. Austin, C.U. Press, I886).

- De Gen. ad Lit. xi c. I. I Ib. viii c. $\mathrm{r}$.

s Praef. lib. v Comm. in Is. (P. L. xxiv $\left.15^{8}\right)$. Cf. also his commentary on Obadiah (P. L. Xxv 1097). I owe these references to M. de Labriolle, op. cit. p. 207. 